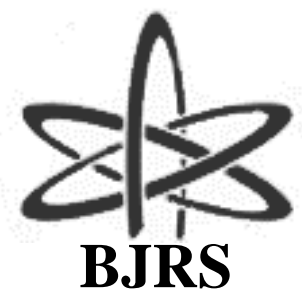

\author{
BRAZILIAN JOURNAL \\ $\mathrm{OF}$ \\ RADIATION SCIENCES \\ 09-01A (2021) 01-11
}

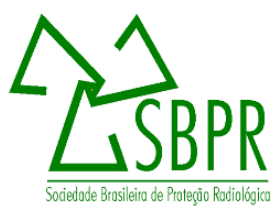

\title{
Elementary characterization of metals in lipsticks by EDXRF spectrometry
}

\author{
Torres ${ }^{\text {a }}$ C.A.M.P., Paschuk ${ }^{\text {a }}$ S. A., Narloch ${ }^{a}$ D. C., Corrêa ${ }^{a}$ J.N. \\ ${ }^{a}$ Federal University of Technology - Paraná, UTFPR \\ Av. Sete de Setembro, 3165 \\ 80230-901 Curitiba, PR - Brasil \\ cata9montenegro@gmail.com, spaschuk@gmail.com
}

\begin{abstract}
Usually classified as cosmetic consumer products, makeups usually contain significant quantities of colorants, which may contain toxic and heavy metals, such as $\mathrm{Hg}, \mathrm{Cd}$, As, Cr, Tl, and Pb. According to the Health Regulatory Agency (ANVISA), lipsticks are classified as low health risk, grade 1. However, similar makeups for the children are classified as grade 2 , high risk, and within this category there is no cosmetic product for embellishment. Many metals, present in the colorants, can cross the mucous membranes and skin barrier and could be absorbed into the blood system, which can cause systemic damage to internal organs. Many chemical components present in the lipsticks, such as $\mathrm{Al}, \mathrm{Pb}, \mathrm{Cd}, \mathrm{Br}, \mathrm{Cu}, \mathrm{Zr}, \mathrm{Cr}, \mathrm{Hg}, \mathrm{TiO}_{2}$ in nanoparticulate form, could be considered as potentially toxic. Present work was undertaken in order to study the presence of mentioned above metals in the samples of commercial lipsticks. The metals characterization and elementary identification was performed using EDXRF technique. This method allows performing the qualitative and quantitative analysis by means of the characteristic $X$-rays spectra emitted by the elements present in studied samples. The experimental setup was based on mini X-ray tube with Ag target and detector (AMPTEK). The partial results of the study revealed that the lipstick samples revealed the presence of $\mathrm{Al}, \mathrm{Si}, \mathrm{S}, \mathrm{Cl}, \mathrm{K}, \mathrm{Ca}, \mathrm{Ti}, \mathrm{Cr}, \mathrm{Fe}, \mathrm{Ni}, \mathrm{Zn}, \mathrm{Br}, \mathrm{Rb}$, which suggest that prolonged and constant use of such cosmetics may constitute a potential threat to the health especially in the case of children.
\end{abstract}

Keywords: Lipsticks, heavy metals, EDXRF. 


\section{INTRODUCTION}

According to the Health Regulatory Agency (ANVISA), lipsticks are classified as low health risk consumer products - Grade 1. However, children's makeup products are classified as grade 2 - high risk. And within this category there is no other cosmetic product for embellishment. Being classified as cosmetics, makeups usually contain significant quantities of colorants, which may contain toxic and heavy metals [1].

According to the World Health Organization (WHO), transplacental exposure is the most dangerous stage because the developing fetal brain is sensitive to toxins and heavy metals [2]. Different studies show that children have from $10 \%$ to $20 \%$ higher absorption rate of such chemical compounds comparing with adults [3].

European Union list of prohibited substances in cosmetics has elements such as chlorine $(\mathrm{Cl})$, nickel (Ni), arsenic (As), beryllium $(\mathrm{Be})$, cadmium $(\mathrm{Cd})$, chromium $(\mathrm{Cr})$, iodine $(\mathrm{I})$, phosphorus $(\mathrm{P})$, lead $(\mathrm{Pb})$, mercury $(\mathrm{Hg})$, selenium $(\mathrm{Se})$, zirconium $(\mathrm{Zr})$, cobalt $(\mathrm{Co})$ and others (Regulation $\mathrm{n}^{\circ}$ 1223/2009) [4].

According to the Food and Drug Administration (FDA), it was estimated that maximum exposure to lead from a cosmetic lip product should be of $10 \mathrm{ppm}$ and its maximum consumption must be of $0.24 \mu \mathrm{g} / \mathrm{day}$ for adults. And the limit of $0.024 \mu \mathrm{g} / \mathrm{day}$ is established for children of 12 years old or younger, assuming that children use $10 \%$ of these products comparing with adults [5].

The guidance of FDA provides a recommended maximum level of 10 parts per million (ppm) for lead as an impurity in cosmetic lip products and externally applied. This maximum level of lead it is also recommended by the International Cosmetic Regulation Cooperation and regions such as Canada and the European Union [5].

Also, according to FDA, depending on factors such as how frequently we are exposed and during how long time, heavy metals can be considered as toxic or sensitizing factor. The limits for color additives used in cosmetics are: $\mathrm{As}<3 \mathrm{ppm}, \mathrm{Pb}<20 \mathrm{ppm}, \mathrm{Hg}$ not more than $1 \mathrm{ppm}$. The Cr as chromium (III) hydroxide $\left(\mathrm{Cr}(\mathrm{OH})_{3}\right)$ "chrome green", and chromium Oxide Greens $\left(\mathrm{Cr}_{2} \mathrm{O}_{3}\right)$ are both permitted for use as color additives in externally applied cosmetics. However, there is no regulation that limits the use of $\mathrm{Cr}$ in cosmetics specifically, only limits $\mathrm{Cr}$ as an impurity to $50 \mathrm{ppm}$. The FDA 
itself warns of the need to learn more about the levels of metals present in cosmetics, both as an ingredient and as an impurity [5-7].

In Brazil, and the main regulators of the world, there are rules that control the levels of these impurities in lip products, but these standards are insufficient and generalists. ANVISA RDC Regulation No. 83 of June 17, 2016, establishes substances which cannot be used in care products, cosmetics and perfumes. In the list of elements has chlorine $(\mathrm{Cl}), \mathrm{Ni}$, bromine $(\mathrm{Br}), \mathrm{As}, \mathrm{Be}, \mathrm{Cd}, \mathrm{Cr}, \mathrm{I}, \mathrm{P}$, $\mathrm{Pb}, \mathrm{Hg}, \mathrm{Se}, \mathrm{Zr}, \mathrm{Co}[8,9]$.

Many toxic or heavy metals, present in the dyes or pigments, can cross the mucous membranes and skin barrier and when absorbed into the blood system they can cause systemic damage to internal organs [5].

In general, heavy metals may produce cell toxicity and denature proteins. Bromine used as an organic dyes, is agent that suppress the function of bone marrow. The lead, for example, in overt toxicity after a range of exposures, aminoaciduria is the most consistent finding [10].

$\mathrm{Cr}, \mathrm{Pb}, \mathrm{Cd}$, manganese (Mn), As, Hg, Aluminum (Al), and titanium (Ti) it's heavy metals and can be found in lipsticks and makeup in general. These metals may offer great risk to human health, specifically induce to the onset of cancer and until neurotoxicities due aluminum [10].

Toxicity can be defined as the relative ability of a substance to cause adverse effects in living organisms. In addition to dose, other factors may also influence the toxicity of the compound such as the route of entry, duration and frequency of exposure. In the context, the heavy metals such $\mathrm{Hg}, \mathrm{Pb}$, Se and Tl may denature proteins as well as produce cell toxicity. Many chemicals can also cross the skin barrier and be absorbed into the blood system. Once absorbed, they may produce systemic damage to internal organs [11].

Once such metal is absorbed, it usually distributes in tissues and organs. The excretion typically occurs primarily through the kidneys and digestive tract. However, metals tend to remain in kidneys, liver, bones for years or decades. Among the organs more often affected by toxic metals are brain and the kidney [12-13]. The Table 1 shows some examples of such metals and their distribution within internal organs of humans.

Titanium dioxide $\left(\mathrm{TiO}_{2}\right)$ nanoparticles (NPs) are manufactured worldwide in large quantities for use in a wide range of applications such cosmetics, for example. The most common nanomaterials found in consumer products for dermal application are $\mathrm{TiO}_{2} \mathrm{NPs}$. And the manufacturer-identified 
nanotechnology-based consumer products would have long term dermal contact. Following the deposition of NPs at the initial location of exposure, the absorption and translocation to systemic sites is a critical step in toxicokinetic and it is often defined as migration of the NP to organs [14].

The concentration of $\mathrm{TiO}_{2}$ NPs in the human body system depends on the rate of absorption, distribution, metabolism, and excretion. In the context, TiO2 NPs, can be cause DNA damage and interact with the epithelium of the small intestine responsible for absorption of nutrients. These processes may occur after exposure through inhalation, ingestion, dermal contact. Consumer age also can be a factor which has a significant role in the harmful effect of $\mathrm{TiO}_{2} \mathrm{NPs}$. For example, in the case of young rats, liver swelling was observed along with cardiac injuries and non-allergic activation of mast cells in gastric tissue. Yet the case of adult rats, it was observed insignificant liver and renal damage, but TiO2 NPs was related for reduced intestinal permeability [14].

Table 1: Distribution of metals in tissues and organs

\begin{tabular}{|c|c|c|c|c|c|c|c|c|}
\hline Metal & $\begin{array}{c}\text { Central Nervous } \\
\text { System }\end{array}$ & $\begin{array}{l}\text { Digestive } \\
\text { System }\end{array}$ & Lungs & Kidneys & Liver & Heart & Blood & Skin \\
\hline $\mathrm{Al}$ & $\mathrm{X}$ & & $\mathrm{X}$ & & & & & \\
\hline As & $\mathrm{X}$ & $\mathrm{X}$ & $\mathrm{X}$ & $\mathrm{X}$ & $\mathrm{X}$ & & $\mathrm{X}$ & \\
\hline $\mathrm{Be}$ & & & $\mathrm{X}$ & & & & & $\mathrm{X}$ \\
\hline $\mathrm{Bi}$ & & & & $\mathrm{X}$ & $\mathrm{X}$ & & & $\mathrm{X}$ \\
\hline $\mathrm{Cd}$ & $\mathrm{X}$ & $\mathrm{X}$ & $\mathrm{X}$ & $\mathrm{X}$ & $\mathrm{X}$ & $\mathrm{X}$ & & $\mathrm{X}$ \\
\hline $\mathrm{Cr}$ & $\mathrm{X}$ & & $\mathrm{X}$ & $\mathrm{X}$ & $\mathrm{X}$ & & & $\mathrm{X}$ \\
\hline Co & $\mathrm{X}$ & $\mathrm{X}$ & $\mathrm{X}$ & & & $\mathrm{X}$ & & $\mathrm{X}$ \\
\hline $\mathrm{Cu}$ & & $\mathrm{X}$ & & & & & $\mathrm{X}$ & \\
\hline $\mathrm{Fe}$ & $\mathrm{X}$ & $\mathrm{X}$ & $\mathrm{X}$ & & $\mathrm{X}$ & & $\mathrm{X}$ & \\
\hline $\mathrm{Pb}$ & $\mathrm{X}$ & $\mathrm{X}$ & & $\mathrm{X}$ & & & $\mathrm{X}$ & $\mathrm{X}$ \\
\hline $\mathrm{Mn}$ & $\mathrm{X}$ & & $\mathrm{X}$ & & & & & \\
\hline $\mathrm{Hg}$ & $\mathrm{X}$ & $\mathrm{X}$ & $\mathrm{X}$ & $\mathrm{X}$ & & & & \\
\hline $\mathrm{Ni}$ & $\mathrm{X}$ & & $\mathrm{X}$ & & & & & $\mathrm{X}$ \\
\hline $\mathrm{Se}$ & & $\mathrm{X}$ & & $\mathrm{X}$ & & & & $\mathrm{X}$ \\
\hline $\mathrm{Zn}$ & & & $\mathrm{X}$ & & & & $\mathrm{X}$ & \\
\hline
\end{tabular}

Source: Adapted from Klaassen; Watkins (2012)

Energy dispersive X-ray fluorescence (EDXRF) spectrometry is a nondestructive, rapid, multielement, highly accurate, and environment friendly analysis compared with other elemental evaluation 
methods. Thus, EDXRF spectrometry is applicable for production quality control, ecological environment monitoring, geological surveying, food inspection, and heritage analysis, among others [15].

In EDXRF spectrometers, all chemical elements in the sample are excited simultaneously. An energy dispersive detector in combination with a multichannel analyzer is used to collect the fluorescence radiation emitted from the sample and then separate the different energies of the characteristic radiation from each of the different chemical elements [16].

Present work was undertaken in order to determine the presence the heavy metals and potentially toxic elements, such as $\mathrm{Al}, \mathrm{Pb}, \mathrm{Cd}, \mathrm{Br}$, copper $(\mathrm{Cu}), \mathrm{Zr}, \mathrm{Cr}, \mathrm{Hg}$, Ti and others, in children's lipsticks and adults' makeups.

\section{MATERIALS AND METHODS}

Present survey of chemical elements characterization of the samples of cosmetic consumer products was performed using EDXRF experimenter equipment at the Laboratory of Applied Nuclear Physics of Federal University of Technology - Paraná (UTFPR), Curitiba-PR, Brazil.

\subsection{Experimental Setup}

The EDXRF spectrometer kit consists of X-ray tube with silver (Ag) target, and silicon drift detector SDD-123 (Amptek), which was chosen as the most appropriate for this research due to its compact arrangement and quick analysis, which produce very reliable results when compared with other elemental detection methods

\subsection{Samples}

Present survey was performed using 14 samples of lipsticks (8 adults' samples and 6 children samples). The 14 samples lipsticks are national and popular brand. All were randomly purchased, except for the color criterion. The colors analyzed were in shades of red and pink. The Figure 1 shows experimental kit equipped with X-ray tube with Ag target for the analysis of lipstick samples. 
Figure 1: Experimental setup applied for the analysis of lipstick samples.

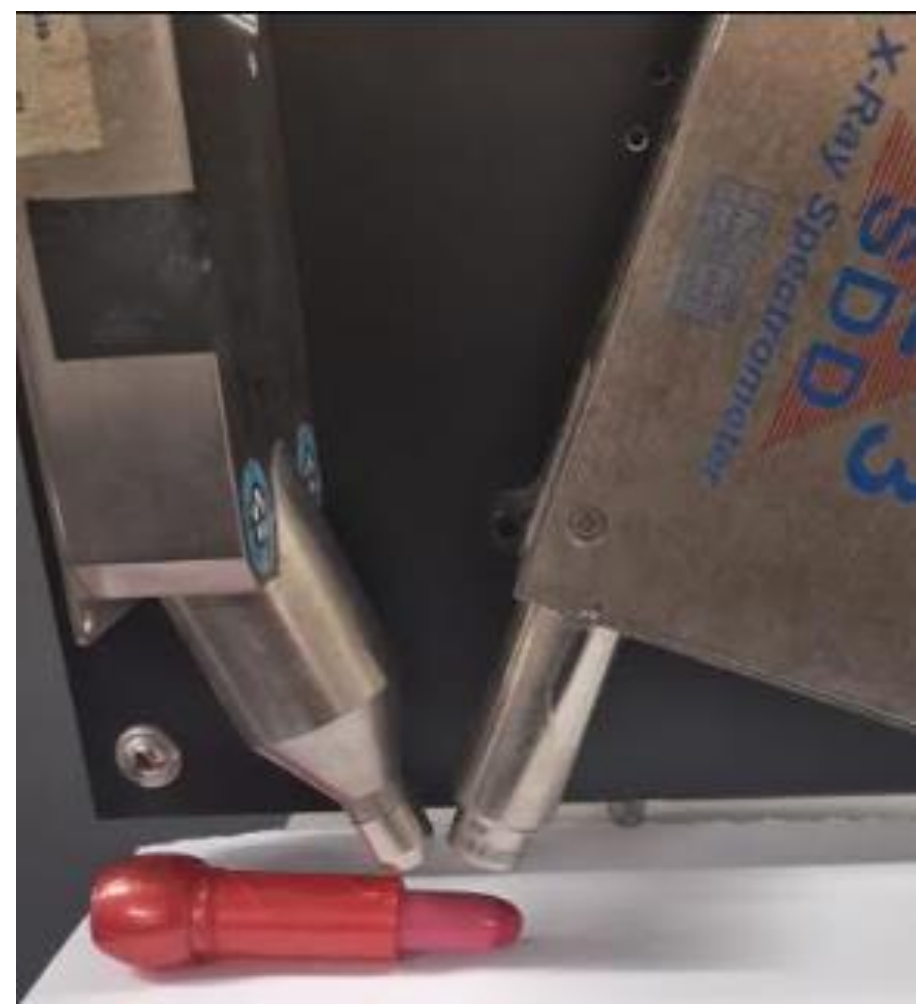

Source: Author

\subsection{Technical Parameters}

The measurements of X-ray spectra were performed with X-ray tube with Ag target with applied electric potential of $30 \mathrm{kV}$ and electric current of $15 \mu \mathrm{A}$ during $600 \mathrm{~s}$ with installed collimator of $1.0 \mathrm{~mm}$ of internal diameter. During the measurements the distance between the X-ray tube-detector set and the sample was maintained of $11 \mathrm{~mm}$, which is suggested by AMPTEK user manual.

The calibration of the equipment was done using the calibration plate of the spectrometer kit itself, using $30 \mathrm{kVp}$ and current to $30 \mu \mathrm{A}$. The characteristic of X-ray peaks from different elements is used for the characterization of each element. 


\section{RESULTS AND DISCUSSION}

In general, obtained results showed that the elemental compositions of all studied samples of children's lipsticks and adult's makeup were very similar presenting the characteristic peaks (Characteristic X-ray emission lines) of aluminum (Al), silicon ( $\mathrm{Si})$, sulfur ( $\mathrm{S}), \mathrm{Cl}$, potassium $(\mathrm{K})$, calcium (Ca), Ti, Cr, iron (Fe), Br, rubidium ( $\mathrm{Rb})$.

The toxic elements such as $\mathrm{Pb}, \mathrm{Cd}, \mathrm{Zr}, \mathrm{Hg}$ and $\mathrm{As}$ were not detected in samples analyzed. Probably, because they are not present in the samples or due to their low concentrations.

Figure 2 shows the examples of experimental EDXRF spectra obtained during adult's lipstick characterization. The adult's lipstick, sample B2 - Pink matte lipstick, elemental composition determined by EDXRF analysis shows Al, Ca, Ti, Fe and Br. The adult's lipstick, sample B7 - Pink lipstick, elemental composition determined by EDXRF analysis shows $\mathrm{Al}, \mathrm{Si}, \mathrm{Ca}, \mathrm{Ti}, \mathrm{Cr}, \mathrm{Fe}, \mathrm{Rb}$.

Figure 2: Spectra of elementary characterization in adult's lipsticks, samples B2 and B7

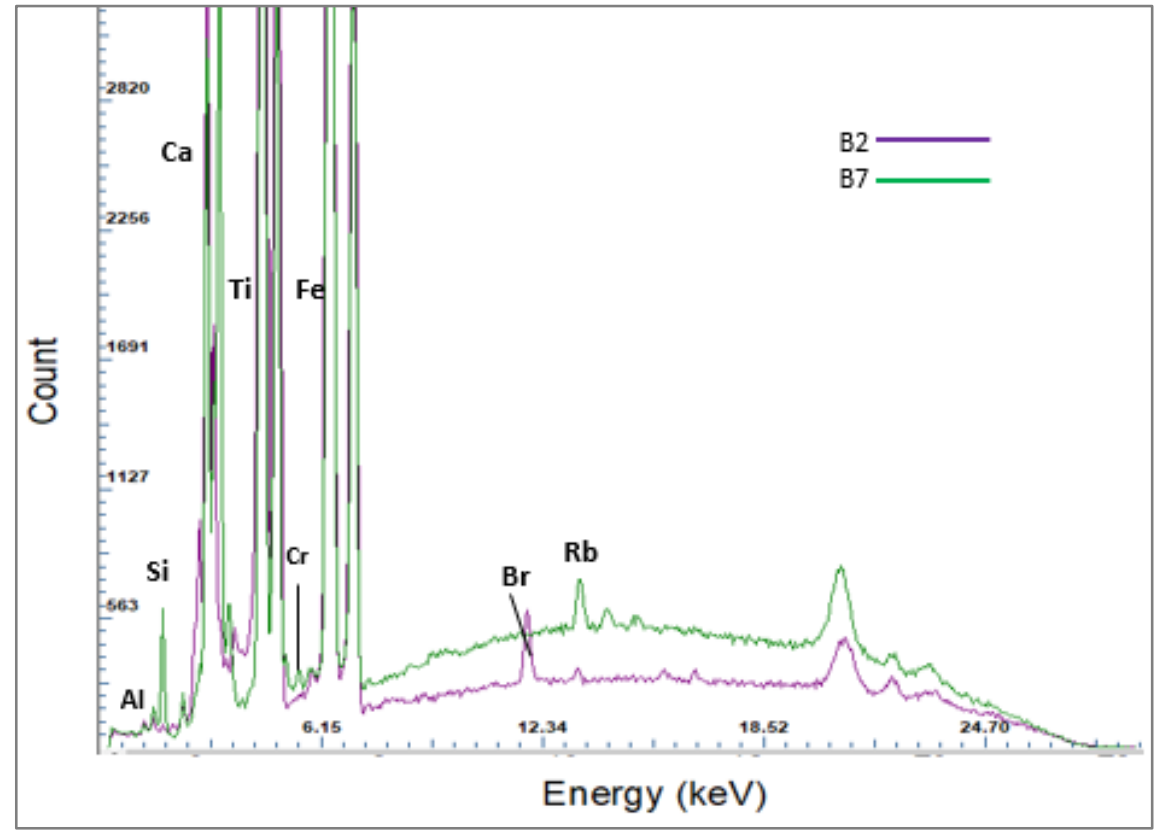

Source: Author

Figure 3 shows the examples of experimental EDXRF spectra obtained during infant lipstick characterization. The children's lipstick, sample LSc1- Pink lipstick, elemental composition shows $\mathrm{Al}, \mathrm{Si}, \mathrm{Ti}, \mathrm{Fe}, \mathrm{Cu}$ and Br. The lipstick children, sample LSc2- sparkling rose lipstick, elemental 
composition shows $\mathrm{Al}, \mathrm{Si}, \mathrm{Ti}, \mathrm{Fe}, \mathrm{Cu}$ and $\mathrm{Br}$. However, the lipstick children, sample LSc3- Red lipstick, elemental composition shows $\mathrm{Al}, \mathrm{Si}, \mathrm{Ti}$, with element $\mathrm{Cr}$ and larger intensity peaks for $\mathrm{Cu}$ and $\mathrm{Br}$. These characteristics are due to properties of red pigment.

Figure 3: Spectra elementary characterization children's lipstick of the samples LSc1, LSc2, LSc3

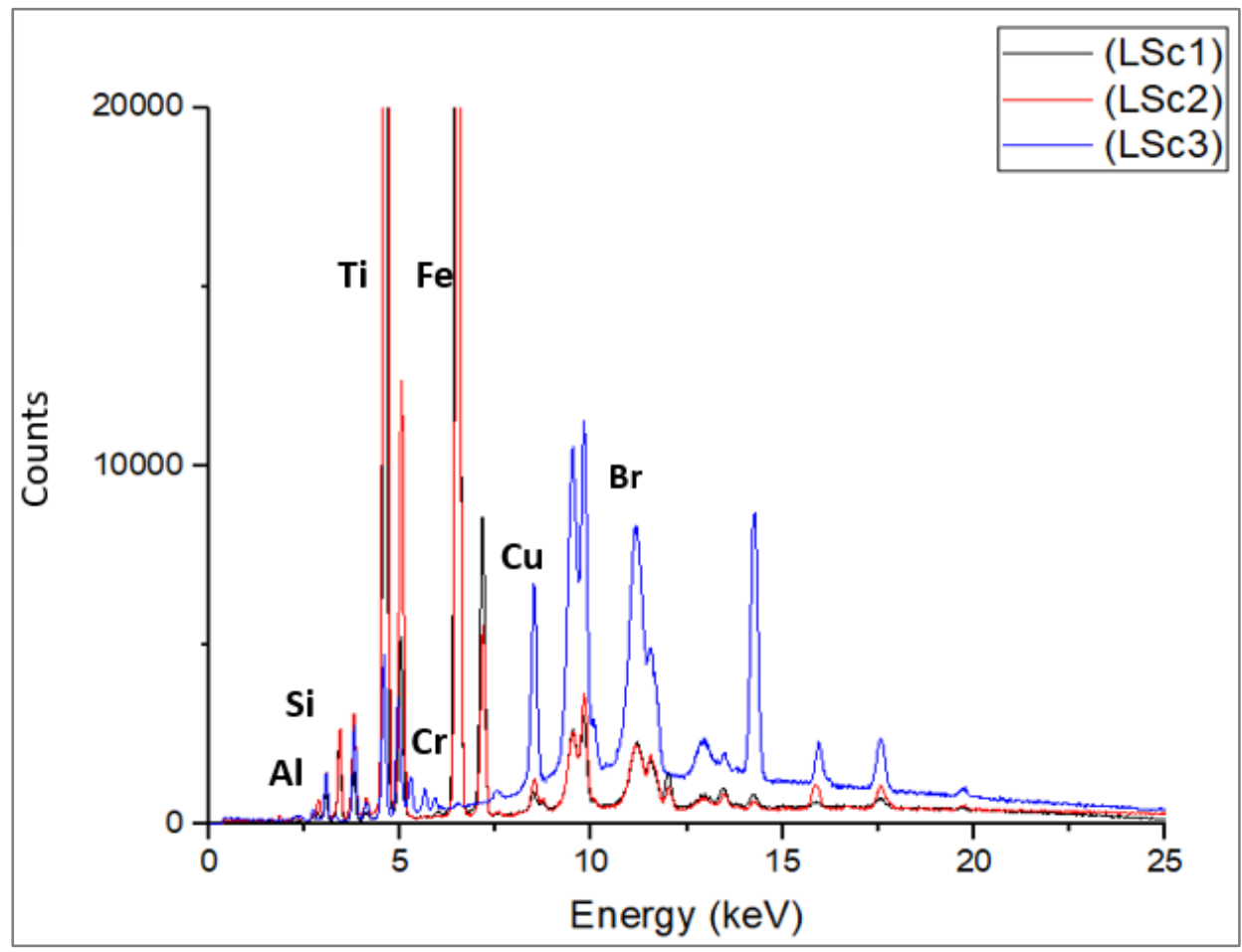

Source: Author

It can be noticed that in the case of children's lipstick the EDXRF spectrum presents the characteristic peaks of toxic metals such as $\mathrm{Al}, \mathrm{Cr}, \mathrm{Fe}$ and $\mathrm{Cu}$. In the case of adult's makeup, the EDXRF spectrum revealed the presence of $\mathrm{Al}, \mathrm{Cr}, \mathrm{Fe}$ and $\mathrm{Rb}$. Both groups of samples of infant and adults' cosmetics revealed the presence of highly toxic Br. All samples indicate the presence of Ti, presumed to be associated with liver edema, cardiac lesions and non-allergic activation of mast cells in gastric tissue.

Due the technical parameters used in this research, the qualitative analysis showed the best results reached with EDXRF technique. 
The EDXRF is one of the best analytical techniques to perform elemental analysis in all kinds of samples non-destructively. This technique provides a combined highest accuracy and precision with simple and fast sample preparation for the analysis.

In addition, it is the best choice for dedicated applications in quality and process control. The performed analysis of experimental data shows that the cosmetic products that were analyzed in this study very likely contained harmful chemical elements such as $\mathrm{Al}, \mathrm{Si}, \mathrm{Ti}, \mathrm{Fe}, \mathrm{Cr}, \mathrm{Br}$ and $\mathrm{Rb}$ in both adult's and children's lipsticks.

\section{CONCLUSION}

Due to the presence of heavy metals, the extended use of such products may constitute a potential threat to the health especially in the case of children. Therefore, it has to be recommended to establish the maximum acceptable limits for potential contaminants in the cosmetic consumer products as well as good manufacturing practices around the world. In general, the makeup industry has been mostly self-regulated for more than a century. We need tougher regulations and more education and information around cosmetics in general and especially makeup for kids.

\section{ACKNOWLEDGMENT}

The authors are very thankful to Coordenação de Aperfeiçoamento de Pessoal de Nível Superior (CAPES) and the Graduate Course in Electrical Engineering and Industrial Informatics (CPGEI, UTFPR) for financial support.

\section{REFERENCES}

[1] BRASIL: ANVISA - Brazilian Health Regulatory Agency. Regulation RDC ANVISA 79 de 25 de agosto de 2000 - DOU de 31/08/2000. 6 p. Diário Oficial, República Federativa do Brasil. Poder Executivo, Brasília, DF, 2000. 
[2] KARIN, F. N.; SHAH, A. Do not put makeup on children, say health experts. New Straits Times, 2016.

[3] SIDORYK-WEGRZYNOWICZ, M.; ASCHNER, M. Manganese toxicity in the central nervous system: the glutamine/glutamate- $\gamma$-aminobutyric acid cycle. J Inter Med v. 273, p. 466-477 (2013): 466-77. doi:10.1111/joim.12040.

[4] EC - European Parliament and of the Council Regulation no 1223/2009 of the of 30 november 2009 on cosmetic products. Official Journal of the European Union, 2009. Available at :< https://ec.europa.eu/health/sites/health/files/endocrine_disruptors/docs/cosmetic_1223_2009 regulation_en.pdf. Last accessed: 12 Mar. 2020.

[5] U.S. Food and Drug Administration, Limiting Lead in Lipstick and Other Cosmetics, December 2016. Available at $:<$ http://www.fda.gov/Cosmetics/ProductsIngredients/Products/ucm137224.htm> Last accessed : 10 Mai. 2020.

[6] U.S. Food and Drug Administration, FDA's Testing of Cosmetics for Arsenic, Cadmium, Chromium, Cobalt, Lead, Mercury, and Nickel Content, December 2016. Available at: <http://www.fda.gov/Cosmetics/ProductsIngredients/PotentialContaminants/ucm452836.htm Last accessed: 10 Mai. 2020.

[7] U.S. Food and Drug Administration, Draft Guidance for Industry: Lead in Cosmetic Lip Products and Externally Applied Cosmetics: Recommended Maximum Level, December 2016. 8p. Available at: https://www.fda.gov/media/99866/download. Last accessed: 10 Apr. 2020.

[8] BRASIL: ANVISA - Brazilian Health Regulatory Agency. Regulation RDC no 83, de 20 de junho de 2016 (D.O.U. 116). 121p. Diário Oficial, República Federativa do Brasil. Poder Executivo, Brasília, DF. Available at: http://www.abc-cosmetologia.org.br/wp-content/uploads/2016/06/1RDC_83_2016.pdf (in Portuguese). Last accessed: 03 Jun. 2020.

[9] EC - European Union. Regulation. N1223/2009 of the European Parliament and of the Council of 30 November 2009 on cosmetic products. Official Journal of the European Union, 2009. 151p. Available at: $\quad$ https://ec.europa.eu/health/sites/health/files/endocrine_disruptors/docs/cosmetic_1223_2009_regulation_en.pdf. Last accessed: 03 Apr.2020. 
[10] GONDAL, M.A.; SEDDIGI, Z.S.; MOHAMED M. N.; GONDAL, B. Spectroscopic detection of health hazardous contaminants in lipstick using Laser Induced Breakdown Spectroscopy. J Hazard Mater, v. 175, p.726-732, 2010. Available at: http://www.ncbi.nlm.nih.gov/pubmed/ 19926220. Last accessed: 07 Jun. 2020.

[11] UNL. University of Nebraska Lincoln. Toxicology and exposure guidelines. Environmental Health and Safety (402) 472-4925. Available at: https://ehs.unl.edu/documents/tox_exposure_guidelines.pdf Last acessed: 14 Mai. 2020.

[12] KLAASSEN, C. D., WATKINS III, J. B. Fundamentos em toxicologia de Casarett e Doull. Lange, AMGH, 2012.

[13] JAN, A.T.; AZAM, M.; SIDDIQUI, K.; ALI, A.; CHOI, I.; HAQ, Q.M. Heavy metals and human health: mechanistic insight into toxicity and counter defense system of antioxidants. Int J. Mol Sci, v. 16,12 p. $29592-630.10$ Dec. 2015 , doi: 10.3390/ijms161226183

[14] SHI, H.; MAGAYE, R.; CASTRANOVA, V.; ZHAO, J. Titanium dioxide nanoparticles: a review of current toxicological data. Part Fibre toxicol, v. 10, p. 2-24, 2013. doi:10.1186/17438977-10-15. Available at: https://particleandfibretoxicology.biomedcentral.com/track/pdf/10.1186/1743-8977-10-15 Last accessed: 07 Mar. 2020.

[15] GAUGLITZ, G.; VO-DINH, T. Handbook of spectroscopy. v.1, p. 363-415. WILEY-VCH Verlag GmbH \& Co. KGaA, Weinheim, 2003.

[16] GRIEKEN, R. E. V.; MARCOWICZ, A. A. Handbook of x-ray spectrometry. 2. ed. New York, Marcel Dekker Inc, 2002. 